\title{
The influence of the elements of procedural justice and speed camera enforcement on young novice driver self-reported speeding
}

\author{
Lyndel Bates*
}

School of Criminology and Criminal Justice and Griffith Criminology Institute, Griffith University, Brisbane, Australia

Centre of Accident Research and Road Safety - Queensland (CARRS-Q), Institute for Health and Biomedical Innovation, Queensland University of Technology, Brisbane, Australia

Email: 1.bates@griffith.edu.au

Phone: 61737351429

Siobhan Allen

School of Criminology and Criminal Justice, Griffith University, Brisbane, Australia

Barry Watson

Global Road Safety Partnership, Geneva, Switzerland

Centre of Accident Research and Road Safety - Queensland (CARRS-Q), Institute for Health and Biomedical Innovation, Queensland University of Technology, Brisbane, Australia

*Corresponding Author

Revised version submitted to Accident Analysis and Prevention on 10 March 2016 


\title{
The influence of the elements of procedural justice and speed camera enforcement on young novice driver self-reported speeding
}

\author{
Road policing is an important tool used to modify road user behaviour. While \\ other theories, such as deterrence theory, are significant in road policing, there \\ may be a role for using procedural justice as a framework to improve outcomes in \\ common police citizen interactions such as traffic law enforcement. This study, \\ using a sample of 237 young novice drivers, considered how the four elements of \\ procedural justice (voice, neutrality, respect and trustworthiness) were perceived \\ in relation to two forms of speed enforcement: point-to-point (or average) speed \\ and mobile speed cameras. Only neutrality was related to both speed camera \\ types suggesting that it may be possible to influence behaviour by emphasising \\ one or more elements, rather than using all components of procedural justice. \\ This study is important as it indicates that including at least some elements of \\ procedural justice in more automated policing encounters can encourage citizen \\ compliance.
}

Keywords: procedural justice; speed cameras; average speed enforcement; road policing; neutrality; novice drivers

\section{Highlights:}

- This study applies the four elements of procedural justice: voice, neutrality, respect and trustworthiness

- The neutrality of the speed camera is associated with lower levels of young novice drivers speeding

- It may be possible to influence driver behaviour using only some elements of procedural justice

\section{Introduction}

Road policing is a key element in the modification of driver behaviour in most jurisdictions worldwide (Bates, Soole, \& Watson, 2012). Traditionally deterrence theory has been the most common framework used in the design, implementation and 
evaluation of road policing countermeasures (Bates et al., 2012; Fleiter, Watson, \& Lennon, 2013). Despite this, there may be value in using a procedural justice framework in addition to the more traditional theoretical frameworks used in road policing (Bates, 2014).

While theories such as deterrence theory are focussed on the outcomes of an interaction or countermeasure, procedural justice refers to the processes associated with the interaction. Thus, deterrence theory relies on encouraging compliance by creating the perception that drivers will be caught and punished if they offend. It therefore implies that people make a rational decision about whether to break traffic laws (such as travelling above the posted speed limit, running red lights etc.) based on the balance of positives and negatives of engaging in the behaviour (Bradford, Hohl, Jackson, \& MacQueen, 2015). In contrast, procedural justice suggests that the way the interaction occurs influences subsequent behaviour. Hence, drivers who have a positive interaction with police as a result of their offending behaviour (such as travelling above the posted speed limit etc.), even if it results in a penalty or sanction, are more likely to comply with road rules in the future. Research suggests that when individuals consider the fairness of the interaction, compared to the outcome of the interaction, they indicate that fairness is more important (Murphy, 2004; Tyler, 2011). Procedural justice can occur in a range of interactions in a criminal justice context including policing (e.g. Bradford, 2014; Elliott, Thomas, \& Ogloff, 2014; Gau \& Brunson, 2010), the courts (e.g. Knox Mahoney, 2013; Thibaut \& Walker, 1978) and prisons (e.g. Beijersbergen, Dirkzwager, Eichelsheim, Van der Laan, \& Nieuwbeerta, 2015).

\section{Procedural justice}

Procedural justice is proposed to consist of four components: voice, neutrality, respect and trustworthiness (Goodman-Delahunty, 2010; Sargeant, Murphy, Davis, \& 
Mazerolle, 2012). Voice refers to citizens being provided with the opportunity to communicate their view prior to the authority making a decision (Bates, 2014; Murphy \& Barkworth, 2014). Neutrality occurs when the police make judgements based on facts rather than any pre-existing biases or beliefs (Murphy, Mazerolle, \& Bennett, 2014). Transparency is an important part of neutrality (Goodman-Delahunty, 2010). It is also important that citizens are treated appropriately and politely, which is captured by the respect component (Murphy \& Barkworth, 2014; Murphy et al., 2014). Trust occurs when individuals believe that the police are genuinely concerned about their well-being and that they are trying to do their best for the citizen (Bates, 2014; GoodmanDelahunty, 2010). It is more important for these four principles to be incorporated in interactions that are initiated by police when compared with those initiated by citizens (Murphy, 2009; Skogan, 2005).

Additionally, procedural justice can occur at both a global and a local level. Global procedural justice occurs when a generalised evaluation is made of a decisionmaking power at a group level (Gau, 2014). These perceptions are shaped in a range of ways which may have little to do with actual interactions between police and citizens. For instance, the media, friends and family may be sources of information on which relevant perceptions are based. Specific procedural justice occurs when individuals make an evaluation of an authority based on a particular encounter (Gau, 2014). Thus, specific procedural justice is based on a particular interaction between police and citizens and whether the officer demonstrated voice, neutrality, respect or trustworthiness.

Ethnicity does appear to affect procedural justice (Sargeant, Murphy, \& Cherney, 2014; Tyler, 2005, 2011), with, for example, procedural justice less useful in fostering cooperation with police for individuals with a Vietnamese or Indian 
background when compared with a general Australian population group (Sargeant et al., 2014). Social identity, where individuals explore and make sense of belonging to a particular social group, also appears important (Oliveira \& Murphy, 2015; Sargeant, Antrobus, Murphy, Bennett, \& Mazerolle, 2014, online first). Oliveira and Murphy (2015) found that social identity was more important than ethnic status in predicting attitudes towards police. Research, with participants still studying at school, identified that procedural justice was important for young people in terms of the impact on cooperation with police (Murphy, 2015) and for their perceptions of police legitimacy (Akinlabi, 2015, online first).

Research suggests that there a number of benefits associated with procedurally just policing. These include citizens being more likely to believe that the police are legitimate (Bradford, Murphy, \& Jackson, 2014; Jonathan-Zamir \& Weisburd, 2013; Mazerolle, Bennett, Davis, Sargeant, \& Manning, 2013; Sunshine \& Tyler, 2003), cooperate with police (Bradford, 2014) and for them to have trust in police (De Cremer \& Tyler, 2007; Tyler, 2005). One study with male domestic violence perpetrators considered whether the use of procedural justice in interactions with offenders affected subsequent offending. Even when the interaction with police for the perpetrator's first offence had an adverse outcome, if the interaction incorporated the principles of procedural justice they were less likely to reoffend (Paternoster, Brame, Bachman, \& Sherman, 1997).

Most studies in the area of procedural justice policing have focussed on interpersonal interactions (Murphy, 2009). Despite this, one study has indicated that confidence in police can be enhanced by non-interpersonal interactions. Within the United Kingdom, a field quasi-experiment found that a letterbox drop could enhance public confidence with police (Hohl, Bradford, \& Stanko, 2010). 


\section{Procedural justice and road policing}

Given the importance of procedural justice in police-citizen interactions for a range of outcomes, there is a need for a greater understanding of the role of procedural justice within a road policing context. This is because of the significant number of interactions that occur between police and citizens at traffic stops or in other road policing situations (J. Allen, Edmonds, Patterson, \& Smith, 2006; Engel, 2005; Hoover, Dowling, \& Fenske, 1998; Roberts \& Indermaur, 2009; Skogan, 1990). Despite the significant body of research examining procedural justice, very little has occurred within a road policing context (Bates, 2014). One extensive study that did so was the Queensland Community Engagement Trial (QCET).

QCET was a randomised criminological field experiment that examined the impact of police officers using the principles of procedural justice in their interactions with drivers at a routine traffic stop, the random breath test. QCET involved 20,985 participants that completed either a standard or a procedurally just random breath test with police officers. A standard routine breath test in Queensland can be administered in either a stationary (roadblock) or mobile (interception by a police vehicle) mode. However, in the QCET trial, the police used a stationary operation which involves setting up checkpoints in assorted places. Motorists who travelled past these checkpoints were randomly selected and breath tested by police. Drivers exhaled into a plastic tube attached to a device that measured their blood alcohol level. It is a very short and standardised interaction between drivers and police (Ferris et al., 2013). In the procedurally just QCET random breath test, police were briefed by senior officers prior to each breath testing operation that they were going to explicitly incorporate the four principles of procedural justice into each interaction. The police were provided with a small cue card that contained relevant prompts for them to encourage the incorporation 
of the elements of procedural justice (Mazerolle, Bennett, Antrobus, \& Tyler, 2013). Drivers that were in the procedurally just interaction condition were more likely to report that their views on drinking and driving had changed. Additionally, they reported higher levels of satisfaction with police and greater compliance during the encounter (Mazerolle, Bennett, Antrobus, \& Eggins, 2012). Drivers’ perceptions of police were more positive for both the specific encounter and more broadly (Mazerolle, Bennett, Antrobus, et al., 2013). However, a replication of QCET undertaken in Scotland (ScotCET) did not improve general trust in police or police legitimacy possibly indicating the difficulties in translating police interventions across contexts (McQueen \& Bradford, 2015).

Undertaking a procedurally just road policing interaction does appear to take more time. A standard interaction within QCET averaged 25.51 seconds (sd $=4.84$ seconds) while a procedurally just interaction averaged 99.11 seconds (sd $=30.01$ seconds). Interestingly, research does suggest that when the interaction was longer than 1 minute and 50 seconds there was a reduction in the positive perceptions of police performance (Mazerolle et al., 2015). It also appears as if a procedurally just encounter affects police perceptions as well as drivers with police who conduct procedurally just random breath tests more likely to report that this program is about deterring drivers from drinking and driving and showing a police presence in the community (Bates, Antrobus, Bennett, \& Martin, 2015).

Another Australian study involved 148 participants who completed a 20 minute online survey examining the use of procedural justice within a speeding scenario. Participants were randomly allocated to either a procedurally just or a procedurally unjust scenario. Both scenarios involved participants being pulled over by police for travelling five kilometres above the speed limit. In the procedurally just scenario the 
police officer engages with the driver in a manner that is courteous and friendly. They explain why the driver was pulled over and provide an opportunity for them to explain their speeding behaviour. In contrast, in the procedurally unjust scenario, the police officer is rude and uses disrespectful language, does not explain why they were pulled over and the driver does not have the opportunity to explain their behaviour. Those participants allocated to the procedurally just scenario were more likely to indicate that they would comply in the future. However, it does appear that negative emotions mediate this relationship (Barkworth \& Murphy, 2015).

Research suggests that the perceived legitimacy of police enforcement for different types of driving behaviours varies. A study with a sample of Australian drivers identified that of four behaviours, driving without a seatbelt, driving while fatigued, speeding and driving under the influence of alcohol, there was less perceived legitimacy for the enforcement of speeding and driving while fatigued (Watling \& Leal, 2012). More recent research supports this finding for drink driving and sleepy driving (Watling \& Watling, 2015). This suggests that researchers and policy makers need to consider if procedural justice has a different effect for different road offences, particularly given that one of the outcomes of procedural justice is perceived legitimacy. This highlights that the interactions that occur in a road setting are quite variable and can involve direct police enforcement or indirect involvement, such as through automated enforcement. One example of automated enforcement are speed cameras. In this type of interaction between police and citizens there is no face-to-face contact between the police officer and the driver which limits the ability for the driver to communicate with the police officer and the police officer to use their discretion. 


\section{Speeding}

Speeding is a problematic behaviour on the road as it increases both the risk of crashing and the severity of injuries in the event of a crash (Aarts \& van Schagen, 2006; P. J. Cooper, 1997; Williams, Kyrychenko, \& Retting, 2006). Enforcement, and particularly automated enforcement of speeding through the use of speed cameras, appears important in reducing the occurrence of speeding behaviours by drivers (Williams et al., 2006; Wilson, Willis, Hendrikz, Le Brocque, \& Bellamy, 2010). Additionally, we need to understand driver perceptions about their interactions with enforcement mechanisms, such as speed cameras, as these perceptions are likely to be more influential on behaviour than actual enforcement levels and practices (Fleiter, Watson, Lennon, King, \& Shi, 2009).

Around the world, a variety of different speed cameras are now used including fixed, mobile and average speed enforcement. Fixed speed cameras are located in one place and do not move. They tend to operate 24 hours per day and are unmanned (Carnis \& Blais, 2013). Mobile speed cameras are operated from a vehicle that is parked on the roadside (Jones, Sauerzapf, \& Haynes, 2008). Research has shown that fixed and mobile speed cameras are an effective policing mechanism that reduce crashes (Pilkington \& Kinra, 2005; Wilson et al., 2010). Average speed enforcement is the most recent speed camera development and involves a series of cameras installed at a number of points along the road to measure and assess the average speed of vehicles over a set distance (Soole, Watson, \& Fleiter, 2013). Average speed enforcement is also known as point-to-point speed enforcement, section control or trajectory control (Soole et al., 2013) and evidence suggests that these types of cameras do reduce driver speeds (De Pauw, Daniels, Brijs, Hermans, \& Wets, 2014; Hoye, 2014; Montella, Imbriani, 
Marzano, \& Mauriello, 2015). Thus, each type of speed camera, while seeking to reduce driver speeds, does so in a different manner.

Research suggests, in the context of speeding enforcement, 'fairness' is an important concept for drivers with individuals perceiving speed cameras to be consistent but unfair as they do not allow drivers the opportunity to display their voice within the interaction (Wells, 2008). Drivers that had collected points for speeding offences indicated that they thought aspects of the system such as the placement of the cameras, the perception that they were used to raise revenue and the penalty points system were unfair (Corbett \& Grayson, 2010). However, focus group research with drivers in Queensland, Australia does suggest that they are more supportive of speed camera programs that are operated in an overt and transparent manner (Soole, Lennon, \& Watson, 2008). This is consistent with the view that speed cameras are a 'fairer' approach to speed enforcement as they treat all vehicles the same regardless of driver characteristics (S. Cooper, 2010).

\section{Young drivers and speeding}

Young, newly licensed drivers have higher crash rates compared to all other groups of drivers (Bates, Davey, Watson, King, \& Armstrong, 2014). Research does suggest that age is a factor associated with greater levels of self-reported speeding (Fleiter et al., 2009; Williams et al., 2006) with speeding appearing to be a relatively frequent behaviour in young drivers. An Australian study with 165 young drivers aged 17 to 25 years who held either a provisional or open drivers’ licence found that $92.7 \%$ of the sample reported speeding greater than 10 kilometres per hour over the speed limit at least once in the past month (Harbeck \& Glendon, 2013). Additional factors that affect the speeding behaviour of young drivers include gender, ownership of vehicle, attitudes towards speeding and whether they have high levels of the sensation seeking 
trait (Scott-Parker, Hyde, Watson, \& King, 2013). Additionally, having risky friends appears to encourage young drivers to speed (Simons-Morton et al., 2012). There is emerging research suggesting that young drivers' levels of compliance on the road is not deterred by police enforcement (Bates, Darvell, \& Watson, 2015, online first). Thus, we need to consider alternative theoretical approaches to improve our enforcement approaches targeted at this group. Procedural justice policing has shown to have a positive effect on young people, with recent research even suggesting that procedural justice is more important for young people than adults (Murphy, 2015). Whist not explored in the driving context, this suggests that procedural justice may indeed play a role in young drivers’ behaviour.

\section{Current study}

The current study used a sample of newly licensed young drivers from Queensland, Australia to explore how various elements of procedural justice are associated with mobile and average speed camera enforcement mechanisms. Drivers in this Australian state are required to gain a licence through a graduated driver licensing system (Bates, 2010; Scott-Parker, Bates, Watson, King, \& Hyde, 2011). Graduated driver licensing systems have three phases: learner (must drive under supervision), provisional or intermediate (able to drive by themselves but subject to certain restrictions) and open (Bates, Allen, et al., 2014). In Queensland, there are two provisional driver licences (S. Allen, Murphy, \& Bates, 2015, online first). Young drivers can obtain a P1 licence from 17 years of age which is held for 12 months. While driving on this licence, they must have a zero blood alcohol concentration, can not use their cell phones and may only have one peer passenger beyond a certain time of night. The P2 licence is held for two years and drivers must have a zero blood alcohol concentration. Both P1 and P2 drivers must display P-plates to indicate their licence 
status to other road users (S. Allen et al., 2015, online first). Research suggests that graduated driver licensing systems reduce crashes for the young driver group (Bates, Allen, et al., 2014; Masten \& Foss, 2010; Pressley, Benedicto, Trieu, Kendig, \& Barlow, 2009; Shope, 2007). The aim of this study was to explore young driver perceptions of procedural justice associated with speed cameras and the influence of this on their speeding behaviour.

\section{Methods}

\section{Participants and procedure}

Participants in this study were drivers who held a Queensland provisional driver's licence and were aged between 17 and 24 years. They were asked, in a 30 minute online survey, questions regarding their perceptions of different types of speed camera enforcement and police performance. Participants were recruited through flyers, email lists from a major metropolitan university and an undergraduate student research pool. Participants from the student research pool were offered course credit for completion of the survey. No other incentives were offered.

Of the 237 participants within this sample, the majority were female (71.8\%), with a mean age of 18.67 years $(S D=1.55)$. The split between those holding a P1 licence and those on a P2 licence was relatively even, with 54\% of respondents on a P1 licence and $46 \%$ of participants on a P2 licence. The gender balance was similar across both licence types $\left(X^{2}(1)=.60, p=.44\right)$.

Participants were made aware that the data collected would remain anonymous. Submission of a completed survey indicated that respondents consented to participate in the study. The study was approved by the Queensland University of Technology Human Research Ethics Committee (13000000542) before commencing. Data collection 
occurred between 11 October 2013 and 20 June 2014. The study reported here is part of a larger program of research examining young novice drivers and road policing (Bates et al., 2015, online first).

\section{Measures}

A range of measures were incorporated into the survey including socio-demographic characteristics, self-reported compliance with the speeding laws, whether the drivers reported avoiding police and perceptions of procedural justice related to speed camera enforcement.

\section{Socio-demographic characteristics}

Socio-demographic variables were measured at the start of the survey. It is important to control the influence of socio-demographic characteristics in quantitative research as it allows the study to be comparable across other studies and jurisdictions in the field of driver compliance (Freeman et al., 2006). Socio-demographic items measured in this study include age $(M=18.67, S D=1.55)$, gender $(0=$ male; $1=$ female $)$, and licence status $(0=\mathrm{P} 1 ; 1=\mathrm{P} 2)$.

\section{Warnings of police presence}

This measure, warnings of police presence, was a single item adapted from Scott-Parker (2012). The item asked drivers “do you pay attention to warnings about police presence on the road, such as mobile speed cameras, random breath tests etc?”. This question was used as a control variable in the models to capture whether this behaviour contributed to self-reported speeding behaviour. 


\section{Police avoidance}

This measure was a single item adapted from Scott-Parker (2012). The item asked participants “do you avoid the areas where you know police are, or are likely to be?”. This question was used as a control variable in the analyses to identify if any differences in self-reported speeding were found between those who attempted to avoid police detection and those who did not.

\section{Perceptions of procedural justice}

This procedural justice scale, adapted from Mazerolle et al. (2012), measured participants' perceptions of procedural justice across two different situations. The first situation asked participants to imagine receiving a speeding ticket as a result of committing a speeding offence and being caught by a mobile speed camera. Participants were informed that this involved one police officer in a roadside location setting up the speed camera and then monitoring the camera from his van. The seven items, ${ }^{1}$ on a fivepoint Likert scale, asked participants to indicate how much they disagreed (1) or agreed (5) with the police in enforcing the law through the use of the mobile speed camera. This same approach was adopted for the point-to-point speed cameras, asking

\footnotetext{
${ }^{1}$ Items for the procedural justice mobile and point-to-point speed camera enforcement scale (adapted from Mazerolle et al. 2012) were:

Imagine you have been sent a speeding ticket as a result of committing a speeding offence and being caught by a mobile/point-to-point speed camera.

The police were fair when making the decision to place a speed camera in this location*

The police gave me the opportunity to express my views

The police listened to me

The police treated me with dignity and respect

The police were polite when dealing with me

I felt that the police were trustworthy

I had confidence the police were doing the right thing

*Adapted for this study
} 
participants to indicate how much they disagreed (1) or agreed (5) with the police in enforcing the speed laws through the use of point-to-point speed cameras. Participants were advised that this involved a series of cameras used on a stretch of road that measured their speed at the start and then at the end before averaging their speed between the two points. The decision regarding whether you are speeding is based on this average speed.

According to Mazerolle et al. (2012), the perceptions of procedural justice scale has good internal consistency, with their study reporting a Cronbach alpha coefficient of .92. In the current study the Cronbach alpha coefficient for the mobile speed camera scenario was .87, and for the point-to-point speed camera scenario the Cronbach alpha coefficient was .88.

\section{Procedural Justice components}

As noted earlier, procedural justice contains several components which are grouped into the categories voice, neutrality, respect, and trust (Murphy et al., 2014). Various subscales were created using the items from the perceptions of procedural justice scale adapted from Mazerolle et al. (2012). Trust was measured with the items 'I felt the police were trustworthy' and 'I had confidence that the police were doing the right thing' (mobile cameras $\alpha=.72$; point to point cameras $\alpha=.78$ ). The two items in the dignity sub-scale were 'The police treated me with dignity and respect and 'The police were polite when dealing with me' (mobile cameras $\alpha=.86$; point to point cameras $\alpha=$ .91). Voice was measured with the items 'The police gave me the opportunity to express my views' and 'The police listened to me' (mobile cameras $\alpha=.91$; point to point cameras $\alpha=.92$ ). Neutrality was measured with the single item 'The police were fair when making the decision to place a speed camera in this location'. 


\section{Self-reported speeding}

This measure contained four items which asked questions about driver's compliance on the road. The items used a 5-point Likert scale from 'never' to 'nearly all the time' to rate drivers' self-reported rule breaking. Four items related to speeding were summed to create a composite measure. The items were 'you drove over the speed limit in areas where it was unlikely there was a radar or speed camera'; 'you went 10-20 km/hr over the speed limit'; 'you went up to $10 \mathrm{~km} / \mathrm{hr}$ over the speed limit'; and 'you went more than $20 \mathrm{~km} / \mathrm{hr}$ over the speed limit'. Simply, the more a participant reported being noncompliant with these items, the higher their speeding score would become. The nature of a composite measure means it cannot be tested for internal consistency. However, more participants reported that they never drove at more than $20 \mathrm{~km} / \mathrm{hr}$ (70.9\%) over the speed limit than those at the $10-20 \mathrm{~km} / \mathrm{hr}$ level (43.5\%) or the up to $10 \mathrm{~km} / \mathrm{hr}$ over the speed limit (20.7\%) indicating basic consistency within the scale. The questions were adapted from the Behaviour of Young Novice Drivers Scale (BYNDS) created by ScottParker, Watson, and King (2010).

\section{Results}

Table 1 presents the means, standard deviations, and Cronbach's reliability coefficients for each scale. As the self-reported speeding measure was not a scale item, there is no Cronbach's reliability coefficient reported. Four hierarchical regressions were used to examine whether young driver perceptions of procedural justice were related to self-reported speeding behaviour.

\section{Table 1}

Means, Standard Deviations, and Cronbach's Reliability Coefficients of Scales $(N=237)$

\begin{tabular}{lrrrr}
\hline Variable & $\begin{array}{r}\text { No. of } \\
\text { items }\end{array}$ & M & SD & $\begin{array}{r}\text { Cronbach } \\
\text { alpha }\end{array}$ \\
\hline Perceptions of PJ - mobile speed camera* & 7 & 3.06 & .72 & .87
\end{tabular}




\begin{tabular}{lcccc} 
Perceptions of PJ - point-to-point camera* & 7 & 3.00 & .74 & .88 \\
$\begin{array}{l}\text { Perceptions of neutrality - mobile speed } \\
\text { camera* }\end{array}$ & 1 & 3.42 & 1.02 & n/a \\
$\begin{array}{l}\text { Perceptions of neutrality - point-to-point } \\
\text { camera* }\end{array}$ & 1 & 3.43 & 1.01 & n/a \\
$\begin{array}{l}\text { Perceptions of trust - mobile speed } \\
\text { camera* }\end{array}$ & 2 & 3.38 & .81 & .72 \\
$\begin{array}{l}\text { Perceptions of trust - point-to-point } \\
\text { camera* }\end{array}$ & 2 & 3.30 & .88 & .78 \\
$\begin{array}{l}\text { Perceptions of dignity \& respect - mobile } \\
\text { speed camera* }\end{array}$ & 2 & 3.14 & .83 & .86 \\
$\begin{array}{l}\text { Perceptions of dignity \& respect - point- } \\
\text { to-point camera* }\end{array}$ & 2 & 2.99 & .88 & .91 \\
$\begin{array}{l}\text { Perceptions of voice - mobile speed } \\
\text { camera }\end{array}$ & 2 & 2.47 & .99 & .91 \\
$\begin{array}{l}\text { Perceptions of voice - point-to-point } \\
\text { camera* }\end{array}$ & 2 & 2.48 & .98 & .92 \\
Self-reported speeding** & 4 & 8.36 & 3.45 & n/a \\
\hline
\end{tabular}

Note:

* Scale measured on a 1 (disagree) to 5 (agree) scale.

** Scores can range from 0 to 20.

The first regression analysis included gender, age, licence type (P1 or P2), policing warnings and police avoidance in the first step and perceptions of procedural justice related to mobile speed camera use in the second step to identify if these were related to self-reported speeding behaviour. As shown in Table 2, both steps in the regression were significant with licence type $(\beta=.22$, $\mathrm{p}<.01)$, police warnings ( $\beta=$ $.13, \mathrm{p}<.05)$ and police avoidance $(\beta=-.15, \mathrm{p}<.01)$ significant in the first model and licence type $(\beta=.22, \mathrm{p}<.01)$ and policing warnings $(\beta=-.13, \mathrm{p}<.05)$ significant in the second model. Perceptions of procedural justice related to mobile speed cameras approached significance $(\beta=-.12, \mathrm{p}=.058)$ suggesting that there may be a relationship between this form of procedural justice and self-reported speeding behaviour.

Therefore, drivers on a P2 licence, those who pay attention to warnings of police presence, avoid areas where they know police are or are likely to be, are more likely to 
report higher levels of self-reported speeding. Overall, this regression analysis explains 14 per cent of self-reported speeding behaviour.

Table 2

Hierarchical multiple regression model for the effect of perceptions of PJ associated with mobile speed cameras on self-reported speeding

\begin{tabular}{|c|c|c|c|c|c|c|}
\hline \multirow[b]{2}{*}{ Variable } & \multicolumn{3}{|c|}{ Model 1} & \multicolumn{3}{|c|}{ Model 2} \\
\hline & B & Std. Err. & $\beta$ & $\mathrm{B}$ & Std. Err. & $\beta$ \\
\hline \multicolumn{7}{|l|}{ Step 1} \\
\hline Gender & -.80 & .48 & -.10 & -.65 & .48 & -.09 \\
\hline Age & .12 & .15 & .05 & .13 & .15 & .06 \\
\hline Licence type & 1.51 & .47 & $.22 * *$ & 1.50 & .47 & $.22 * *$ \\
\hline Policing warnings & -1.38 & .70 & $-.13 *$ & -1.42 & .69 & $-.13 *$ \\
\hline Police avoidance & -1.10 & .46 & $-.15 * *$ & -.87 & .47 & -.12 \\
\hline \multicolumn{7}{|l|}{ Step 2} \\
\hline $\begin{array}{l}\text { Perceptions of PJ - } \\
\text { mobile speed camera }\end{array}$ & & & & -.60 & .31 & $-.12^{\mathrm{a}}$ \\
\hline$R^{2}$ & & & $.12 * * *$ & & & $.14^{* * *}$ \\
\hline Adjusted $R^{2}$ & & & .10 & & & .11 \\
\hline$R^{2}$ change & & & .12 & & & $.01^{\mathrm{b}}$ \\
\hline$F$ change & & & $6.35 * * *$ & & & 3.63 \\
\hline $\mathrm{df}$ & & & 5 & & & 1 \\
\hline
\end{tabular}

Note: $* p<.05 ; * * p<.01 ; * * * p<.001$.

a approached significance $p=.058$

$\mathrm{b}$ the rounding of figures means that numbers do not add up exactly

The second regression, shown in Table 3, examines perceptions of procedural justice associated with point-to-point speed cameras. Socio-demographic variables, policing warnings and policing avoidance were entered into the first step and perceptions of procedural justice related to point-to-point speed cameras were entered into the second step. Overall the regression explained $14 \%$ of the variance in selfreported speeding behaviour with licence type $(\beta=.22, p<.01)$, policing warnings $(\beta=$ $-.13, p<.05)$ and police avoidance $(\beta=-.15, p<.05)$ the significant predictors in the first model suggesting that drivers on a P2 licence, or those who pay attention to warnings of police presence and avoid areas where police are or are likely to be report 
higher levels of speeding. In the second model, the significant predictors were licence type $(\beta=.22, p<.01)$ and perceptions of procedural justice $(\beta=-.1 .38, p<.001)$ associated with point-to-point speed cameras suggesting that those driving on a P2 licence and with lower perceptions of procedural justice associated with point-to-point speed cameras were more likely to report speeding behaviour. Both policing warnings $(\beta=-.12, p=.055)$ and police avoidance $(\beta=-.12, p=.056)$ approached significance.

\section{Table 3}

Hierarchical multiple regression model for the effect of perceptions of $P J$ associated with point-to-point speed cameras on self-reported speeding

\begin{tabular}{|c|c|c|c|c|c|c|}
\hline \multirow[b]{2}{*}{ Variable } & \multicolumn{3}{|c|}{ Model 1} & \multicolumn{3}{|c|}{ Model 2} \\
\hline & $\mathrm{B}$ & Std. Err. & $\beta$ & $\mathrm{B}$ & Std. Err. & $\beta$ \\
\hline \multicolumn{7}{|l|}{ Step 1} \\
\hline Gender & -.80 & .48 & -.10 & -.72 & .48 & -.09 \\
\hline Age & .12 & .15 & .05 & .11 & .15 & .05 \\
\hline Licence type & 1.51 & .47 & $.22 * *$ & 1.50 & .47 & $.22 * *$ \\
\hline Policing warnings & -1.38 & .70 & $-.13^{*}$ & -1.33 & .69 & $-.12^{\mathrm{a}}$ \\
\hline Police avoidance & -1.10 & .46 & $-.15^{*}$ & -.89 & .47 & $-.12^{\mathrm{b}}$ \\
\hline \multicolumn{7}{|l|}{ Step 2} \\
\hline $\begin{array}{l}\text { Perceptions of PJ - } \\
\text { point-to-point camera }\end{array}$ & & & & -.64 & .30 & $-1.38 *$ \\
\hline$R^{2}$ & & & $.12 * * *$ & & & $.14^{* * *}$ \\
\hline Adjusted $R^{2}$ & & & .10 & & & .12 \\
\hline$R^{2}$ change & & & .12 & & & .02 \\
\hline$F$ change & & & $6.35 * * *$ & & & $4.71 *$ \\
\hline df & & & 5 & & & 1 \\
\hline
\end{tabular}

Note: ${ }^{*} p<.05 ; * * p<.01 ; * * * p<.001$.

a approached significance $p=.055$

b approach significance $p=.056$

Given that there appears to be a relationship between procedural justice associated with speed cameras and self-reported speeding behaviours, a further analysis was conducted to examine the association with the four components of procedural justice (neutrality, voice, respect and trust). Thus, in the third regression (Table 4), gender, age, licence type, policing warnings, and police avoidance were entered in the 
first model. Of these predictors, licence type $(\beta=.22, p<.01)$, policing warnings $(\beta=$ $.13, p<.05)$ and police avoidance $(\beta=-.15, p<.05)$ were significant. In the second model, licence type $(\beta=.21, p<.01)$ was significant and policing warnings approached significance $(\beta=-.12, p=.055)$. Of the four elements of procedural justice, only the neutrality element $(\beta=-.20, p<.01)$ was a significant predictor. This suggests that the higher perceptions of the neutrality associated with mobile speed cameras is linked with lower levels of drivers’ self-reported speeding behaviour. Overall, this regression explained $16 \%$ of self-reported speeding behaviour by young novice drivers.

\section{Table 4}

Hierarchical multiple regression model for the effect of perceptions of PJ components associated with mobile speed cameras on self-reported speeding

\begin{tabular}{|c|c|c|c|c|c|c|}
\hline \multirow[b]{2}{*}{ Variable } & \multicolumn{3}{|c|}{ Model 1} & \multicolumn{3}{|c|}{ Model 2} \\
\hline & $\mathrm{B}$ & Std. Err. & $\beta$ & B & Std. Err. & $\beta$ \\
\hline \multicolumn{7}{|l|}{ Step 1} \\
\hline Gender & -.78 & .48 & -.10 & -.56 & .49 & -.07 \\
\hline Age & .11 & .15 & .05 & .11 & .15 & .05 \\
\hline Licence type & 1.50 & .47 & $.22 * *$ & 1.48 & .47 & $.21 * *$ \\
\hline Policing warnings & -1.40 & .70 & $-.13^{*}$ & -1.33 & .69 & $-.12^{\mathrm{a}}$ \\
\hline Police avoidance & -1.08 & .46 & $-.15^{*}$ & -.67 & .48 & -.09 \\
\hline \multicolumn{7}{|l|}{ Step 2} \\
\hline Neutrality & & & & -.69 & .26 & $-.20 * *$ \\
\hline Voice & & & & .19 & .28 & .06 \\
\hline Dignity \& respect & & & & -.09 & .37 & -.02 \\
\hline Trust & & & & -.16 & .39 & -.04 \\
\hline$R^{2}$ & & & $.12 * * *$ & & & $.16^{* * *}$ \\
\hline Adjusted $R^{2}$ & & & .10 & & & .13 \\
\hline$R^{2}$ change & & & .12 & & & .04 \\
\hline$F$ change & & & $6.16 * * *$ & & & $2.77^{*}$ \\
\hline $\mathrm{df}$ & & & 5 & & & 4 \\
\hline
\end{tabular}

Note: $* p<.05 ; * * p<.01 ; * * * c$.

a approached significance $p=.055$

The final regression, shown in Table 5,examined the association between perceptions of procedural justice elements associated with point-to-point speed cameras on self-reported speeding. It explained $16 \%$ of the relationship between these variables. 
In the first step, socio-demographic variables, licence type, policing warnings and police avoidance were entered with licence type $(\beta=.22, p<.01)$, policing warnings ( $\beta$ $=-.13, p<.05)$ and police avoidance $(\beta=-.15, p<.05)$ significant predictors. The four elements of procedural justice were included in the second step. In the second step, the significant predictors were licence type $(\beta=.15, p<.05)$ and neutrality $(\beta=-.16, p<$ .05) indicating that drivers on a P2 licence and with lower perceptions of neutrality associated with point-to-point speed cameras were more likely to report higher levels of speeding. Police avoidance $(\beta=.09, p=.051)$ approached significance. Overall, these regression analyses suggest there is a relationship between procedural justice associated with speed cameras and self-reported speeding behaviour with the most important component of procedural justice in this relationship being neutrality.

\section{Table 5}

Hierarchical multiple regression model for the effect of perceptions of PJ components associated with point-to-point speed cameras on self-reported speeding

\begin{tabular}{|c|c|c|c|c|c|c|}
\hline \multirow[b]{2}{*}{ Variable } & \multicolumn{3}{|c|}{ Model 1} & \multicolumn{3}{|c|}{ Model 2} \\
\hline & $\mathrm{B}$ & Std. Err. & $\beta$ & $\mathrm{B}$ & Std. Err. & $\beta$ \\
\hline \multicolumn{7}{|l|}{ Step 1} \\
\hline Gender & -.80 & .48 & -.10 & -.66 & .14 & .05 \\
\hline Age & .12 & .15 & .05 & .11 & .04 & -.07 \\
\hline Licence type & 1.51 & .47 & $.22 * *$ & 1.43 & .13 & $.15^{*}$ \\
\hline Policing warnings & -1.38 & .70 & $-.13 *$ & -1.27 & .20 & -.05 \\
\hline Police avoidance & -1.10 & .46 & $-.15^{*}$ & -.92 & .13 & $.09^{\mathrm{a}}$ \\
\hline \multicolumn{7}{|l|}{ Step 2} \\
\hline Neutrality & & & & -.56 & .25 & $-.16^{*}$ \\
\hline Voice & & & & -.07 & .29 & -.02 \\
\hline Respect & & & & -.40 & .37 & -.10 \\
\hline Trust & & & & .27 & .36 & .07 \\
\hline$R^{2}$ & & & $.12 * * *$ & & & $.16^{* * * *}$ \\
\hline Adjusted $R^{2}$ & & & .10 & & & .12 \\
\hline$R^{2}$ change & & & .12 & & & .03 \\
\hline$F$ change & & & $6.35 * * *$ & & & 2.16 \\
\hline $\mathrm{df}$ & & & 5 & & & 4 \\
\hline
\end{tabular}


Note: ${ }^{*} p<.05 ; * * p<.01 ; * * * p<.001$.

${ }^{a}$ approached significance $p=.051$

\section{Discussion}

As indicated earlier, procedural justice has been investigated in a range of criminal justice contexts such as policing (e.g. Bradford et al., 2014; Gau \& Brunson, 2010; Haas, Van Craen, Skogan, \& Fleitas, 2015), courts (e.g. Knox Mahoney, 2013) and prisons (e.g. Beijersbergen et al., 2015). In the case of speed camera enforcement, there is no face-to-face contact between a police officer and a driver. This not only removes a driver's ability to communicate with a police officer, but it also excludes a police officer's ability to exercise discretion. The element of police discretion is key within procedural justice (Sunshine \& Tyler, 2003). Sunshine and Tyler (2003) argue that public assessments of the fairness of the manner in which authorities exercise discretion is important in encouraging perceptions of legitimacy and satisfaction of police.

As noted earlier, procedural justice contains four elements that if practiced, encourage positive responses from the community and increased public satisfaction with police (Sunshine \& Tyler, 2003). These elements are voice, respect, neutrality, and trust (Blader \& Tyler, 2003; Murphy et al., 2014). In the policing context, this means if a police officer were to exhibit these elements, drivers would respond positively and have increased levels of trust and confidence in police (Murphy et al., 2014). Increasing perceptions of procedural justice and police performance has been shown to improve public satisfaction and cooperation with police, regardless of the context (Murphy et al., 2014). This means, if procedural justice is exhibited in the road policing context, this is likely to contribute to public attitudes of policing in the larger community. 
In the current study there was a significant relationship between perceptions of procedural justice regarding point-to-point cameras and self-reported speeding behaviour. The relationship approached significance for perceptions of procedural justice associated with mobile speed cameras. This indicates that, despite the lack of face-to-face contact between police officers and citizens, perceived procedural justice can still influence self-reported speeding. However, it appears that not all elements of procedural justice are associated with self-reported speeding with neutrality the only element that was significantly related to both mobile speed cameras and point-to-point speed cameras. This supports the findings of previous research which suggests that the ability to treat all vehicles identically without concern for driver characteristics meant that they are perceived as fair (S. Cooper, 2010) although their inability to provide an opportunity for voice within the interaction is a concern for drivers (Wells, 2008).

Much of the existing procedural justice research has focussed on face-to-face interactions between police officers and citizens (Mazerolle et al., 2015; Murphy, 2009). However, the results of this study indicate that at least some of the procedural justice elements influence driver behaviour in more automated enforcement environments such as when speed cameras are used to encourage driver compliance with speed laws.

Additionally, in all regressions, the more experienced P2 drivers were more likely to report than P1 drivers to have engaged in self-reported speeding behaviours. This is consistent with previous research that indicates that drivers are more likely to break the road laws as they progress through the graduated driver licensing system (S. Allen et al., 2015, online first; Bates et al., 2015, online first; Chapman, Masten, \& Browning, 2014; Scott-Parker, Watson, King, \& Hyde, 2012a). However, it is also likely that, just due to the greater amount of time they have spent on the road, they are more likely to have had a speeding ticket. Therefore, it is unwise to conclude from this 
study that P2 drivers speed more frequently while driving. It is interesting to note that the standardized beta coefficient in the two regressions that included the elements of procedural justice indicates that it accounts for a similar amount of the variance in selfreported speeding compared with the procedural justice element of neutrality. So whilst neutrality appears an important influence on self-reported speeding behaviour, so is the type of licence held by the young novice driver.

It was consistently found that drivers who reported paying attention to warnings of police presence on the roads were more likely to have indicated engaging in speeding. This suggests that, at least among those who pay attention to the warnings, that they may inadvertently increase speeding. This has implications for the strategies used by police and may suggest the need to limit the information provided to drivers regarding speed camera locations. However, given that a large majority of those surveyed indicated that they do pay attention to warnings of police on the roads (89.1\%), there may be other factors that influence speeding behaviour in addition to broadcast warnings of police presence.

The young novice drivers were asked about whether they avoided the areas where they knew police were or were likely to be. The results indicate that those who report avoiding areas where police are, or are likely to be, are more likely to engage in speeding behaviours. This supports the findings of previous research which suggests that unlicensed drivers successfully avoid detection by police (Watson, Armstrong, Watson, Wilson, \& Livingstone, 2011).

\section{Implications}

The results discussed have various implications for procedural justice theory and the policing of young drivers. Firstly, the results indicate that, at least in relation to speed cameras, one element of procedural justice, neutrality, is more relevant than 
others. This suggests that, in different contexts and situations, particular elements of procedural justice may be considered more relevant than others. Thus, it may be possible in certain enforcement situations to focus on ensuring that some, rather than all, elements of procedural justice are present in order to influence the compliance behaviour of individuals. Another implication for procedural justice theory is the application of procedural justice in non-interpersonal enforcement contexts. This study suggests that it is possible for some elements of procedural justice to influence citizens' compliance behaviour even when there is no face-to-face contact between police officers and drivers.

Secondly, as this and other studies suggest that the rates of self-reported offending behaviour increase over time (S. Allen et al., 2015, online first; Bates et al., 2015, online first; Scott-Parker, Watson, King, \& Hyde, 2012b), and that there are significant human and economic costs associated with road trauma (Prenzler, Manning, \& Bates, 2015), there is a need to develop effective and evidence-based countermeasures to reduce offending by young novice drivers. The results of this study suggest that the use of alternate theoretical perspectives such as procedural justice may have value. Another approach worth considering is third-party policing to more effectively enforce this group (Mazerolle \& Ransley, 2005). Finally, as those young novice drivers who report paying attention to warnings are more likely to report speeding behaviour, the police and media may need to consider whether providing warnings of police presence is an appropriate strategy.

\section{Limitations and Future Research}

The findings of this study demonstrate various implications for policing provisionally licensed drivers through speed camera enforcement and the importance of 
the procedural justice element neutrality in this process. There are however several limitations of this research that must be acknowledged. Firstly, the use of self-reported speeding data is a limitation of this study which could be improved in future research through the use of administrative data. However, research with an Australian sample of young drivers suggests that there is a relatively high level of accuracy (83\%) between self-reported traffic offence data and police data (Boufous et al., 2010). Additionally, the data collected is cross-sectional; therefore the conclusions drawn about the predictability of the variables are only speculative. Future research could potentially tease out these findings through experimental or longitudinal research designs. In addition to this, the explained variance in the regressions suggests that there are other variables that contribute to the models that were not captured in this study. Given that parents and family members have a strong impact on young novices' driving behaviours (Taubman-Ben-Ari \& Katz-Ben-Ami, 2013), it is likely that they affect novice drivers’ speeding behaviour as well. Additionally, the presence and behaviour of passengers affects speeding behaviour for this group (Fleiter, Lennon, \& Watson, 2010; Horvath, Lewis, \& Watson, 2012). The inclusion of deterrence-related variables such as direct and indirect experiences of punishment and punishment avoidance may also be useful in explaining some of the variance. These would be important variables to include in future studies. Furthermore, future research should consider if different elements of procedural justice are more important in different types of interactions. Finally, this study adapted an existing procedural justice scale that had been used in a face-to-face road policing interaction, the random breath test (Mazerolle et al., 2012). As a result, there may be issues relating to the relevance of these procedural justice items to speed cameras. Thus, future research could consider developing new items specifically targeted at non face-to-face forms of enforcement such as speed cameras. 
This study examined procedural justice in the context of perceptions of young novice drivers regarding speed camera enforcement. Future research should consider the perceptions of other road user groups. Additionally, there are many different types of enforcement mechanisms used in road policing. There is opportunity to consider if perceptions of procedural justice, and the elements of procedural justice, are distinct in other road policing contexts such as face-to-face speed enforcement or restraint use enforcement.

\section{Conclusion}

This study has important implications for our understanding of the usefulness of procedural justice for young novice drivers in a road policing context. While procedural justice is comprised of four elements: voice, neutrality, respect and trustworthiness, this study identified that only the element of neutrality was associated with self-reported speeding in both the mobile and point to point speed camera context. This suggests that it may be possible to emphasise some, rather than all, elements of procedural justice in enforcement interactions and still influence compliance behaviour. This study also indicates that it is possible to apply elements of procedural justice in non-interpersonal policing interactions. 


\section{References}

Aarts, L., \& van Schagen, I. (2006). Driving speed and the risk of road crashes: A review. Accident Analysis \& Prevention, 38(2), 215-224. doi: 10.1016/j.aap.2005.07.004

Akinlabi, O. M. (2015, online first). Young people, procedural justice and police legitimacy in Nigeria. Policing and Society. doi: $10.1080 / 10439463.2015 .1077836$

Allen, J., Edmonds, S., Patterson, A., \& Smith, D. (2006). Policing and the criminal justice system - public confidence and perceptions: findings from the 2004/05 British Crime Survey. London: Home Office.

Allen, S., Murphy, K., \& Bates, L. (2015, online first). What drives compliance? The effect of deterrence and shame emotions on young drivers' compliance with road laws. Policing and Society. doi: 10.1080/10439463.2015.1115502

Barkworth, J., \& Murphy, K. (2015). Procedural justice policing and citizen compliance behaviour: the importance of emotion. Psychology, Crime \& Law, 21(3), 254273. doi: 10.1080/1068316X.2014.951649

Bates, L. (2010). Parliamentary committees are important in developing policy: Evidence from a Queensland case study. Australasian Parliamentary Review, 25(2), 14-26.

Bates, L. (2014). Procedural justice and road policing: Is it important? Paper presented at the Road Safety Research, Policing and Education Conference, Melbourne, Australia.

Bates, L., Allen, S., Armstrong, K., Watson, B., King, M., \& Davey, J. (2014). Graduated driver licensing: An international review. Sultan Qaboos University Medical Journal, 14(4), 403-412.

Bates, L., Antrobus, E., Bennett, S., \& Martin, P. (2015). Comparing police and public perceptions of a routine traffic encounter. Police Quarterly, 18(4), 442-468. doi: $10.1177 / 1098611115589290$

Bates, L., Darvell, M., \& Watson, B. (2015, online first). Young and unaffected by road policing strategies: Using deterrence theory to explain provisional drivers’ (non)compliance. Australian and New Zealand Journal of Criminology. doi: $10.1177 / 0004865815589824$ 
Bates, L., Davey, J., Watson, B., King, M., \& Armstrong, K. (2014). Factors contributing to young driver crashes: A review. Sultan Qaboos University Medical Journal, 14(3), 297-305.

Bates, L., Soole, D., \& Watson, B. (2012). The effectiveness of traffic policing in reducing traffic crashes. In T. Prenzler (Ed.), Policing and Security in Practice: Challenges and Achievements: Palgrave Macmillan.

Beijersbergen, K., Dirkzwager, A., Eichelsheim, V., Van der Laan, P., \& Nieuwbeerta, P. (2015). Procedural justice, anger, and prisoners' misconduct: A longitudinal study. Criminal Justice and Behavior, 42(2), 196-218. doi: $10.1177 / 0093854814550710$

Blader, S., \& Tyler, T. (2003). A four-component model of procedural justice: Defining the meaning of a "fair" process. Personality and Social Psychology Bulletin, 29(6), 747-758. doi: 10.1177/0146167203252811

Boufous, S., Ivers, R., Senserrick, T., Stevenson, M., Norton, R., \& Williamson, A. (2010). Accuracy of self-report of on-road crashes and traffic offences in a cohort of young drivers: the DRIVE study. Injury Prevention, 16, 275-277.

Bradford, B. (2014). Policing and social identity: procedural justice, inclusion and cooperation between police and public. Policing and Society: An international Journal of Research and Policy, 24(1), 22-43. doi:

$10.1080 / 10439463.2012 .724068$

Bradford, B., Hohl, K., Jackson, J., \& MacQueen, S. (2015). Obeying the rules of the road: Procedural justice, social identity, and normative compliance. Journal of Contemporary Criminal Justice, 31(2), 171-191. doi: $10.1177 / 1043986214568833$

Bradford, B., Murphy, K., \& Jackson, J. (2014). Officers as mirrors: Policing, procedural justice and the (re)production of social identity. British Journal of Criminology, 54(4), 527-550. doi: 10.1093/bjc/azu021

Carnis, L., \& Blais, E. (2013). An assessment of the safety effects of the French speed camera program. Accident Analysis \& Prevention, 51, 301-309. doi: 10.1016/j.aap.2012.11.022

Chapman, E. A., Masten, S. V., \& Browning, K. (2014). Crash and traffic violation rates before and after licensure for novice California drivers subject to different 
driver licensing requirements. Journal of Safety Research, 50, 125-138. doi: 10.1016/j.jsr.2014.05.005

Cooper, P. J. (1997). The relationship between speeding behaviour (as measured by violation convictions) and crash involvement Journal of Safety Research, 28(2), 83-95. doi: 10.1016/S0022-4375(96)00040-0

Cooper, S. (2010). Mechanical Law Enforcement: Speeding and Camera Technology. The Journal of Criminal Law, 74, 409-414. doi: 10.1350/jcla.2010.74.5.656

Corbett, C., \& Grayson, G. (2010). Speed limit enforcement as perceived by offenders: Implications for roads policing. Policing, 4(4), 364-372. doi: 10.1093/police/paq014

De Cremer, D., \& Tyler, T. (2007). The Effects of Trust in Authority and Procedural Fairness on Cooperation. Journal of Applied Psychology, 92(3), 639-649. doi: 10.1037/0021-9010.92.3.639

De Pauw, E., Daniels, S., Brijs, T., Hermans, E., \& Wets, G. (2014). Automated section speed control on motorways: An evaluation of the effect on driving speed. Accident Analysis \& Prevention, 73, 313-322. doi: 10.1016/j.aap.2014.09.005

Elliott, I., Thomas, S., \& Ogloff, J. (2014). Procedural justice in victim police interactions and victims' recovery from victimisation experiences. Policing and Society, 24(5), 588-601. doi: 10.1080/10439463.2013.784309

Engel, R. S. (2005). Citizens' Perceptions of Distributive and Procedural Injustice During Traffic Stops with Police. Journal of Research in Crime and Delinquency, 42(4), 445-481. doi: 10.1177/0022427804272725

Ferris, J., Mazerolle, L., King, M., Bates, L., Bennett, S., \& Devaney, M. (2013). Random Breath Testing in Queensland and Western Australia: What is the Optimum Ratio of Breath Testing to Licensed Drivers? Accident Analysis and Prevention, 60, 181-188.

Fleiter, J., Lennon, A., \& Watson, B. (2010). How do other people influence your driving speed? Exploring the 'who' and the 'how' of social influences on speeding from a qualitative perspective. Transportation Research. Part F: Traffic Psychology and Behaviour, 13(1), 49-62.

Fleiter, J., Watson, B., \& Lennon, A. (2013). Effective punishment experiences: The need for a more comprehensive approach to conceptualising behavioural 
punishers and rewards in a road safety context. In N. Castro (Ed.), Psychology of Punishment: New Research (pp. 1-30). New York: Nova.

Fleiter, J., Watson, B., Lennon, A., King, M., \& Shi, K. (2009). Speeding in Australia and China : a comparison of the influence of legal sanctions and enforcement practices on car drivers. Paper presented at the 2009 Australasian Road Safety Research, Policing and Education Conference : Smarter, Safer Directions, Sydney, Australia.

Freeman, J., Liossis, P., Schonfeld, C., Sheehan, M., Siskind, V., \& Watson, B. (2006). The self-reported impact of legal and non-legal sanctions on a group of recidivist drink drivers. Transportation Research Part F: Traffic Psychology and Behaviour, 9(1), 53-64. doi: 10.1016/j.trf.2005.08.005

Gau, J. (2014). Procedural justice and police legitimacy: A test of measurement and structure. American Journal of Criminal Justice, 39, 187-205. doi: 10.1007/s12103-013-9220-8

Gau, J., \& Brunson, R. (2010). Procedural justice and order maintenance policing: A study of inner-city young men's perceptions of police legitimacy. Justice Quarterly, 27(2), 255-279. doi: 10.1080/07418820902763889

Goodman-Delahunty, J. (2010). Four Ingredients: New Recipes for Procedural Justice in Australian Policing. Policing, 4(4), 403-410. doi: 10.1093/police/paq041

Haas, N., Van Craen, M., Skogan, W. G., \& Fleitas, D. (2015). Explaining officer compliance: The importance of procedural justice and trust inside a police organization. Criminology and Criminal Justice, 15(4), 442-463.

Harbeck, E., \& Glendon, A. I. (2013). How reinforcement sensitivity and perceived risk influence young drivers' reported engagement in risky driving behaviors. Accident Analysis \& Prevention, 54, 73-80.

Hohl, K., Bradford, B., \& Stanko, E. (2010). Influencing trust and confidence in the London Metropolitan Police: Results from an experiment testing the effect of leaflet drops on public opinion. British Journal of Criminology, 50, 491-513. doi: $10.1093 / b j c / a z q 005$

Hoover, L. T., Dowling, J. L., \& Fenske, J. W. (1998). Extent of Citizen Contact With Police. Police Quarterly, 1(3), 1-18. doi: 10.1177/109861119800100302 
Horvath, C., Lewis, I., \& Watson, B. (2012). Peer passenger identity and passenger pressure on young drivers' speeding intentions. Transportation Research Part F: Traffic Psychology and Behaviour, 15, 52-64. doi: 10.1016/j.trf.2011.11.008

Hoye, A. (2014). Speed cameras, section control, and kangaroo jumps-a meta-analysis. Accident Analysis \& Prevention, 73, 200-208. doi: 10.1016/j.aap.2014.09.001

Jonathan-Zamir, T., \& Weisburd, D. (2013). The Effects of Security Threats on Antecedents of Police Legitimacy: Findings from a Quasi-Experiment in Israel. Journal of Research in Crime and Delinquency, 50(1), 3-32. doi: $10.1177 / 0022427811418002$

Jones, A., Sauerzapf, V., \& Haynes, R. (2008). The effects of mobile speed camera introduction on road traffic crashes and casualties in a rural county of England. Journal of Safety Research, 39, 101-110. doi: 10.1016/j.jsr.2007.10.011

Knox Mahoney, M. (2013). Procedural justice and the judge-probationer relationship in a co-occurring disorders court. International Journal of Law and Psychiatry, 37, 260-266. doi: 10.1016/j.ijlp.2013.11.022

Masten, S. V., \& Foss, R. (2010). Long-term effect of the North Carolina graduated driver licensing system on licensed driver crash incidence: A 5-year survival analysis. Accident Analysis \& Prevention, 42, 1647-1652.

Mazerolle, L., Bates, L., Bennett, S., Ferris, J., White, G., \& Antrobus, E. (2015). Optimising the length of random breath tests: Results from the Queensland Community Engagement Trial. Australian \& New Zealand Journal of Criminology, 48(2), 256-276. doi: 10.1177/0004865814532661

Mazerolle, L., Bennett, S., Antrobus, E., \& Eggins, E. (2012). Procedural Justice, Routine Encounters and Citizen Perceptions of Police: Main Findings from the Queensland Community Engagement Trial (QCET). Journal of Experimental Criminology, 8, 343-367. doi: 10.1007/s11292-012-9160-1

Mazerolle, L., Bennett, S., Antrobus, E., \& Tyler, T. (2013). Shaping citizen perceptions of police legitimacy: A randomized field trial of procedural justice. Criminology, 51(1), 33-63. doi: 10.1111/j.1745-9125.2012.00289.x

Mazerolle, L., Bennett, S., Davis, J., Sargeant, E., \& Manning, M. (2013). Procedural justice and police legitimacy: A systematic review of the research evidence. Journal of Experimental Criminology, 9(3), 245-274. doi: 10.1007/s11292-0139175-2 
Mazerolle, L., \& Ransley, J. (2005). Third Party Policing. Cambridge: Cambridge University Press.

McQueen, S., \& Bradford, B. (2015). Enhancing public trust and police legitimacy during road traffic encounters: results from a randomised controlled trial in Scotland. Journal of Experimental Criminology, 11, 419-443. doi:

10.1007/s11292-015-9240-0

Montella, A., Imbriani, L., Marzano, V., \& Mauriello, F. (2015). Effects on speed and safety of point-to-point speed enforcement systems: Evaluation on the urban motorway A56 Tangenziale di Napoli. Accident Analysis \& Prevention, 75, 164178. doi: 10.1016/j.aap.2014.11.022

Murphy, K. (2004). The role of trust in nurturing compliance: A study of accused tax avoiders. Law and Human Behavior, 28(2), 187-209. doi: 10.1023/B:LAHU.0000022322.94776.ca

Murphy, K. (2009). Public satisfaction with police: The importance of procedural justice and police performance in police-citizen encounters. Australian \& New Zealand Journal of Criminology, 42(2), 159-178. doi: 10.1375/acri.42.2.159

Murphy, K. (2015). Does procedural justice matter to youth? Comparing adults' and youths' willingness to collaborate with police. Policing and Society, 25(1), 5376. doi: 10.1080/10439463.2013.802786

Murphy, K., \& Barkworth, J. (2014). Victim willingness to report crime to police: Does procedural justice or outcome matter most? Victims \& Offenders: An International Journal of Evidence-based Research, Policy and Practice, 9(2), 178-204. doi: 10.1080/15564886.2013.872744

Murphy, K., Mazerolle, L., \& Bennett, S. (2014). Promoting trust in police: findings from a randomised experimental field trial of procedural justice policing. Policing and Society: An international Journal of Research and Policy, 24(4), 405-424. doi: 10.1080/10439463.2013.862246

Oliveira, A., \& Murphy, K. (2015). Race, Social Identity, and Perceptions of Police Bias. Race and Justice, 5(3), 259-277. doi: 10.1177/2153368714562801

Paternoster, R., Brame, R., Bachman, R., \& Sherman, L. (1997). Do fair procedures matter? The effect of procedural justice on spouse assault. Law and Society Review, 31(1), 163-204. doi: 10.2307/3054098 
Pilkington, P., \& Kinra, S. (2005). Effectiveness of speed cameras in preventing road traffic collisions and related casualties: systematic review. BMJ, 330, 331-334. doi: 10.1136/bmj.38324.646574.AE

Prenzler, T., Manning, M., \& Bates, L. (2015). The implications of a harm perspective on terrorism, road safety, tobacco, alcohol, illicit drugs and workplace health and safety. Journal of Policing, Intelligence and Counter Terrorism, 10(2), 88101. doi: 10.1080/18335330.2015.1090050

Pressley, J., Benedicto, C., Trieu, L., Kendig, T., \& Barlow, B. (2009). Motor vehicle injury, mortality and hospital charges by strength of graduated driver licensing laws in 36 states. Journal of Trauma, Infection and Critical Care, 67(1), s43s53.

Roberts, L., \& Indermaur, D. (2009). What Australians think about crime and justice: Results from the 2007 Australian survey of social attitudes Australian Institute of Criminology Research and Public Police Series (Vol. 101). Canberra: Australian Institute of Criminology.

Sargeant, E., Antrobus, E., Murphy, K., Bennett, S., \& Mazerolle, L. (2014, online first). Social identity and procedural justice in police encounters with the public: results from a randomised controlled trial. Policing and Society: An international Journal of Research and Policy. doi: 10.1080/10439463.2014.989159

Sargeant, E., Murphy, K., \& Cherney, A. (2014). Ethnicity, trust and cooperation with police: Testing the dominance of the process-based model. European Journal of Criminology, 11(4), 500-524. doi: 10.1177/1477370813511386

Sargeant, E., Murphy, K., Davis, J., \& Mazerolle, L. (2012). Legitimacy and Policing. In T. Prenzler (Ed.), Policing and Security in Practice: Challenges and Achievements. United Kingdom: Palgrave Macmillan.

Scott-Parker, B. (2012). A comprehensive investigation of the risky driving behaviour of young novice drivers. (Doctor of Philosophy), Queensland University of Technology, Queensland, Australia.

Scott-Parker, B., Bates, L., Watson, B., King, M., \& Hyde, M. (2011). The impact of changes to the graduated driver licensing program in Queensland, Australia on the experiences of learner drivers. Accident Analysis \& Prevention, 43, 13011308. 
Scott-Parker, B., Hyde, M., Watson, B., \& King, M. (2013). Speeding by young novice drivers: What can personal characteristics and psychosocial theory add to our understanding? Accident Analysis and Prevention, 50, 242-250.

Scott-Parker, B., Watson, B., \& King, M. (2010). The risky behaviour of young drivers: developing a measurement tool. Paper presented at the 20th Canadian Multidisciplinary Road Safety Conference, Nilton Niagara Falls, Ontario.

Scott-Parker, B., Watson, B., King, M., \& Hyde, M. (2012a). Young and Unlicensed: Risky Driving Before Entering the Licensing System. Traffic Injury Prevention, 13(3), 213-218.

Scott-Parker, B., Watson, B., King, M., \& Hyde, M. (2012b). Young, inexperienced and on the road: do novice drivers comply with road rules? Transportation Research Record.

Shope, J. T. (2007). Graduated driver licensing: Review of evaluation results since 2002. Journal of Safety Research, 38(2), 165-175.

Simons-Morton, B., Ouimet, M. C., Chen, R., Klauer, S., Lee, S., Wang, J., \& Dingus, T. (2012). Peer influence predicts speeding prevalence among teenage drivers. Journal of Safety Research, 43(5-6), 397-403.

Skogan, W. G. (1990). The Police And Public In England And Wales: A British Crime Survey Report. London: Home Office.

Skogan, W. G. (2005). Citizen Satisfaction with Police Encounters. Police Quarterly, 8(3), 298-321. doi: 10.1177/1098611104271086

Soole, D., Lennon, A., \& Watson, B. (2008). Driver perceptions of police speed enforcement: differences between camera-based and non-camera based methods: results from a qualitative study. Paper presented at the 2008 Australasian Road Safety Research, Policing and Education Conference, Adelaide.

Soole, D., Watson, B., \& Fleiter, J. (2013). Effects of average speed enforcement on speed compliance and crashes: A review of the literature. Accident Analysis and Prevention, 54, 46-56. doi: http://dx.doi.org/10.1016/j.aap.2013.01.018

Sunshine, J., \& Tyler, T. (2003). The role of procedural justice and legitimacy in shaping public support for policing. Law and Society Review, 37(3), 513-547.

Taubman-Ben-Ari, O., \& Katz-Ben-Ami, K. (2013). Family climate for road safety: A new concept and measure. Accident Analysis \& Prevention, 54, 1-14. 
Thibaut, J., \& Walker, L. (1978). A theory of procedure. California Law Review, 66, 541-566.

Tyler, T. (2005). Policing in black and white: Ethnic group differences in trust and confidence in the police. Police Quarterly, 8(3), 322-342. doi: $10.1177 / 1098611104271105$

Tyler, T. (2011). Trust and legitimacy: Policing in the USA and Europe. European Journal of Criminology, 8(4), 254-266.

Watling, C., \& Leal, N. (2012). Exploring perceived legitimacy of traffic law enforcement. Paper presented at the ACRS 2012 National Conference, Sydney, Australia.

Watling, C., \& Watling, H. (2015). Sleepy driving and drink driving: attitudes, behaviours, and perceived legitimacy of enforcement of younger and older drivers. Paper presented at the Australasian Road Safety Conference 2015, Gold Coast, Australia.

Watson, B. C., Armstrong, K. A., Watson, A., Wilson, A., \& Livingstone, K. (2011). A roadside survey of unlicensed driving in Queensland. Paper presented at the Australasian Road Safety Research, Policing and Education Conference, Perth Convention and Exhibition Centre, Perth.

Wells, H. (2008). The techno-fix versus the fair cop: Procedural (in)justice and automated speed limit enforcement. British Journal of Criminology, 48, 798817.

Williams, A., Kyrychenko, S., \& Retting, R. (2006). Characteristics of speeders. Journal of Safety Research, 37(3), 227-232.

Wilson, C., Willis, C., Hendrikz, J., Le Brocque, R., \& Bellamy, N. (2010). Speed cameras for the prevention of road traffic injuries and deaths. Cochrane Database of Systematic Reviews(11). doi: 10.1002/14651858.CD004607.pub4. 